\title{
IMPLEMENTASI PEMBELAJARAN SAINTIFIK MELALUI PENGEMBANGAN PERANGKAT PEMBELAJARAN GURU IPA MADRASAH IBTIDAIYAH DI KECAMATAN BUNGAH GRESIK
}

\author{
Oleh: \\ Ahmad Bashri', Ulfi Faizah², Rinie Pratiwi Puspitawati ${ }^{2}$ \\ 1,2Jurusan Biologi, FMIPA Universitas Negeri Surabaya \\ 1ahmadbashri@unesa.ac.id
}

\begin{abstract}
Abstrak
Pembelajaran saintifik menuntut siswa lebih aktif dengan menerapkan langkah-langkah $5 \mathrm{M}$ yaitu mengamati, menanya, mengumpulkan informasi, mengolah informasi, dan mengkomunikasikan. Namun, penerapan pembelajaran saintifik masih belum banyak dilakukan oleh guru madrasah ibtidaiyah di Kecamatan Bungah Gresik. Banyak guru IPA di wilayah Kecamatan Bungah yang belum memahami pendekatan saintifik dalam pembelajaran. Kegiatan PKM ini bertujuan untuk memberikan pelatihan implementasi pembelajaran saintifik dalam bentuk pengembangan rencana pembelajaran bagi para guru madrasah ibtidaiyah di Kecamatan Bungah Gresik. Metode pelaksanaan kegiatan PKM ini dibagi dalam tiga tahap, yaitu tahap persiapan, pelaksanaan, dan evaluasi. Hasil kegiatan menunjukkan bahwa setelah mengikuti pelatihan ini para peserta mampu mengembangkan RPP saintifik. Peserta memberikan tanggapan yang baik terhadap kegiatan pelatihan implementasi pembelajaran saintifik melalui pengembangan RPP mereka.
\end{abstract}

Kata Kunci: Pembelajaran saintifik, RPP, guru IPA MI Kecamatan Bungah

\begin{abstract}
Scientific learning requires students more active in implementing steps of $5 \mathrm{M}$ are observe, ask, gather information, process information, and communicate. However, the application of scientific learning not much done by teachers in the Madrasah Ibtidaiyah Bungah Gresik. Many science teachers in Bungah the Madrasah Ibtidaiyah wasn't understand the scientific approach to learning. The aims of this activity to provide training of scientific learning implementation to developed the lesson plans for teachers in Madrasah Ibtidaiyah Bungah Gresik. The method of implementation PKM activity is divided into three stages: preparation, implementation, and evaluation. The results show that the activity after the training, the teacher of Madrasah Ibtidaiyah Bungah Gresik was able to develop the scientific their lesson plan (RPP). A good response given by the teachers to training the implementation of scientific learning through the development scientific lesson plan (RPP).
\end{abstract}

Keywords: Scientific learning, lesson plan (RPP), science teacher of Madarasah Ibtidaiyah Bungah

\section{PENDAHULUAN}

Pendekatan saintifik adalah konsep dasar yang mewadahi, menginspirasi, menguatkan, dan melatari pemikiran tentang bagaimana metode pembelajaran diterapkan berdasarkan teori tertentu. Kemendikbud (2013) memberikan konsepsi bahwa pendekatan ilmiah (scientific appoach) dalam pembelajaran di dalamnya mencakup komponen: mengamati, menanya, menalar, mencoba/mencipta, menyajikan/mengkomunikasikan. Metode ilmiah merujuk pada teknik-teknik investigasi atas suatu atau beberapa fenomena atau gejala, memperoleh pengetahuan baru, atau mengoreksi dan memadukan pengetahuan sebelumnya. Untuk dapat disebut ilmiah, metode pencarian (method of inquiry) harus berbasis pada bukti-bukti dari objek yang dapat diobservasi, empiris, dan terukur dengan prinsip-prinsip penalaran yang spesifik. Karena itu, metode ilmiah umumnya memuat serangkaian aktivitas pengumpulan 
data melalui observasi atau ekperimen, mengolah informasi atau data, menganalisis, kemudian memformulasi, dan menguji hipotesis.

Media Pendidikan Indonesia (2014) menyatakan penerapan pendekatan saintifik dalam pembelajaran melibatkan keterampilan proses seperti mengamati, mengklasifikasi, mengukur, meramalkan, menjelaskan, dan menyimpulkan. Dalam melaksanakan prosesproses tersebut, bantuan guru diperlukan. Akan tetapi bantuan guru tersebut harus semakin berkurang dengan semakin bertambah dewasanya siswa atau semakin tingginya kelas siswa. Pembelajaran dengan metode saintifik memiliki karakteristik sebagai berikut: 1) berpusat pada siswa; 2) melibatkan keterampilan proses sains dalam mengonstruksi konsep, hukum atau prinsip; 3) melibatkan proses-proses kognitif yang potensial dalam merangsang perkembangan intelek, khususnya keterampilan berpikir tingkat tinggi siswa; 4) dapat mengembangkan karakter siswa.

Blog Resmi Pembelajaran Guru Sekolah Dasar (2014) menjelaskan bahwa pembelajaran saintifik merupakan pembelajaran yang mengadopsi langkah-langkah saintis dalam membangun pengetahuan melalui metode ilmiah. Model pembelajaran yang diperlukan adalah yang memungkinkan terbudayakannya kecakapan berpikir sains, terkembangkannya "sense of inquiry" dan kemampuan berpikir kreatif.

Pelaksanaan pembelajaran dengan pendekaatan saintifik ini masih menjadi kendala bagi para guru madrasah ibtidaiyah (MI), khususnya para guru MI di Kecamatan Bungah Gresik. Jumlah MI di Kecamatan Bungah sebanyak 27 sekolah dan semuanya berstatus sekolah swasta, baik di bawah naungan LP Ma'arif NU maupun Lembaga Pendidikan Muhammadiyah. Kegiatan pengabdian melalui pelatihan pembelajaran saintifik sangat dibutuhkan oleh para guru untuk meningkatkan kualitas pembelajaran di masing-masing MI se-Kecamatan Bungah.

Hasil wawancara dengan tiga kepala MI dan beberapa guru IPA di MI Kecamatan Bungah bahwa para guru MI masih minim pengetahuan tentang pendekatan saintifik, minim pelatihan terkait, dan belum banyak yang menggunakan pendekatan saintifik dalam pembelajaran sehari-hari. Oleh karena itu untuk memberdayakan para guru MI di Kecamatan Bungah agar dapat melaksanakan pembelajaran saintifik di sekolahnya maka perlu diadakan pelatihan implementasi pembelajaran saintifik. Pelatihan ini melibatkan para guru IPA pada $27 \mathrm{MI}$ di Kecamatan Bungah.

Tujuan dari kegiatan ini untuk memberikan pelatihan implementasi pembelajaran saintifik dalam bentuk pengembangan rencana pembelajaran bagi para guru Madrasah Ibtidaiyah di Kecamatan Bungah Gresik.

\section{METODE PELAKSANAAN}

Kegiatan ini dilakukan dengan menggunakan metode pelatihan dalam rangka melatihkan pengimplementasian pembelajaran saintifik. Pada kegiatan ini pendekatannya dilakukan secara teoritis maupun empiris. Secara teoritis, para guru diberikan materi tentang pembelajaran saintifik dilanjutkan diskusi dan tanya jawab. Secara empiris, para guru diberikan kesempatan untuk mengimplemen-tasikan pembelajaran saintifik sesuai dengan mata pelajaran yang diampu dengan membuat perangkat pembelajaran yang sesuai. Kegiatan dilaksanakan melalui beberapa tahap yaitu tahap rintisan, penguatan, dan evaluasi.

Kegiatan PKM yang dilaksanakan terbagi menjadi tiga tahap utama, yaitu tahap rintisan, tahap penguatan, dan tahap evaluasi. Pada tahap rintisan, dilakukan sejumlah kegiatan, antara lain penggalian informasi untuk menetapkan materi dalam mata pelajaran, penentuan pendekatan saintifik yang akan diberikan, sosialisasi tentang pelatihan ini. Berdasarkan hasil penggalian informasi tahap awal ditetapkan bahwa materi dalam mata pelajaran yang akan dilatihkan adalah yang berkaitan dengan materi IPA. Pada tahap penentuan materi ditetapkan bahwa peserta akan menerima materi tentang implementasi pembelajaran saintifik dalam materi yang terkait dengan IPA. Selain itu, peserta juga akan praktik membuat perangkat pembelajaran yang mengimplementasikan pende-katan saintifik. Tahap sosialisasi tentang pelatihan ini dilakukan dengan penyampaian informasi menggunakan surat undangan.

Tahap penguatan dilaksanakan melalui sesi pelatihan yang dilakukan di salah satu MI 
di Kecamatan Bungah Greseik, tahap ini merupakan pertemuan pertama dengan peserta pelatihan. Pada tahap ini khalayak sasaran diberi materi tentang pembelajarn saintifik dan diberi contoh penerapannya dalam pembelajaran. $\mathrm{Di}$ akhir kegiatan pelatihan, para peserta diminta membuat perangkat pembelajaran dengan pendekatan saintifik secara mandiri di tempat kerja masing-masing.

Tahap evaluasi dilakukan untuk mengukur respons peserta pelatihan terhadap kegiatan pelatihan serta mengukur kemampuan peserta dalam membuat perangkat pembelajaran dengan pendekatan saintifik. Kriteria hasil pelatihan sebagaimana Tabel 1.

Tabel 1. Kriteria Evaluasi Hasil Pelatihan

\begin{tabular}{llll}
\hline No. & \multicolumn{1}{c}{ Aspek Penilaian } & \multicolumn{1}{c}{ Indikator } & \multicolumn{1}{c}{ Uraian } \\
\hline 1. & $\begin{array}{l}\text { Respons peserta } \\
\text { program terhadap } \\
\text { kegiatan }\end{array}$ & $\begin{array}{l}\text { Lebih dari 75\% peserta } \\
\text { memberikan respons } \\
\text { positif terhadap kegiatan } \\
\text { pelatihan }\end{array}$ & $\begin{array}{l}\text { Diukur dengan menggunakan } \\
\text { angket yang diisi oleh peserta }\end{array}$ \\
\hline 2. & $\begin{array}{l}\text { Kemampuan peserta } \\
\text { pelatihan dalam } \\
\text { membuat perangkat } \\
\text { pembelajaran }\end{array}$ & $\begin{array}{l}\text { Lebih dari 75\% peserta } \\
\text { telah mampu membuat } \\
\text { perangkat pembelajaran } \\
\text { dengan pendekatan } \\
\text { saintifik. }\end{array}$ & $\begin{array}{l}\text { Diukur dengan menggunakan } \\
\text { penilaian hasil perangkat } \\
\text { pembelajaran yang dibuat para } \\
\text { guru. }\end{array}$ \\
\hline
\end{tabular}

\section{HASIL DAN PEMBAHASAN}

Keterlaksanaan program ini dinilai berdasarkan dua aspek, yaitu kemampuan peserta dalam mengembangkan perangkat pembelajaran saintifik dan respon peserta terhadap pelatihan.

\section{Kemampuan Peserta dalam Mengembangkan Perangkat Pembelajaran}

Pelaksanaan pelatihan implementasi pembelajaran saintifik melalui pengembangan perangkat pembelajaran diikuti oleh perwakilan dari 27 madrasah ibtidaiyah (MI) se Kecamatan Bungah. Peserta diberikan materi tentang pendekatan saintifik dalam pembelajaran kemudian melakukan analisis rancangan perangkat pembelajaran (RPP) milik peserta pelatihan. Di akhir pertemuan, peserta diberikan tugas mengembangkan perangkat pembelajaran masing-masing dan diberikan feedback untuk perbaikan. Hasil perbaikan perangkat pembelajaran dinilai. Dokumentasi kegiatan pelatihan sebagaimana Gambar 1.

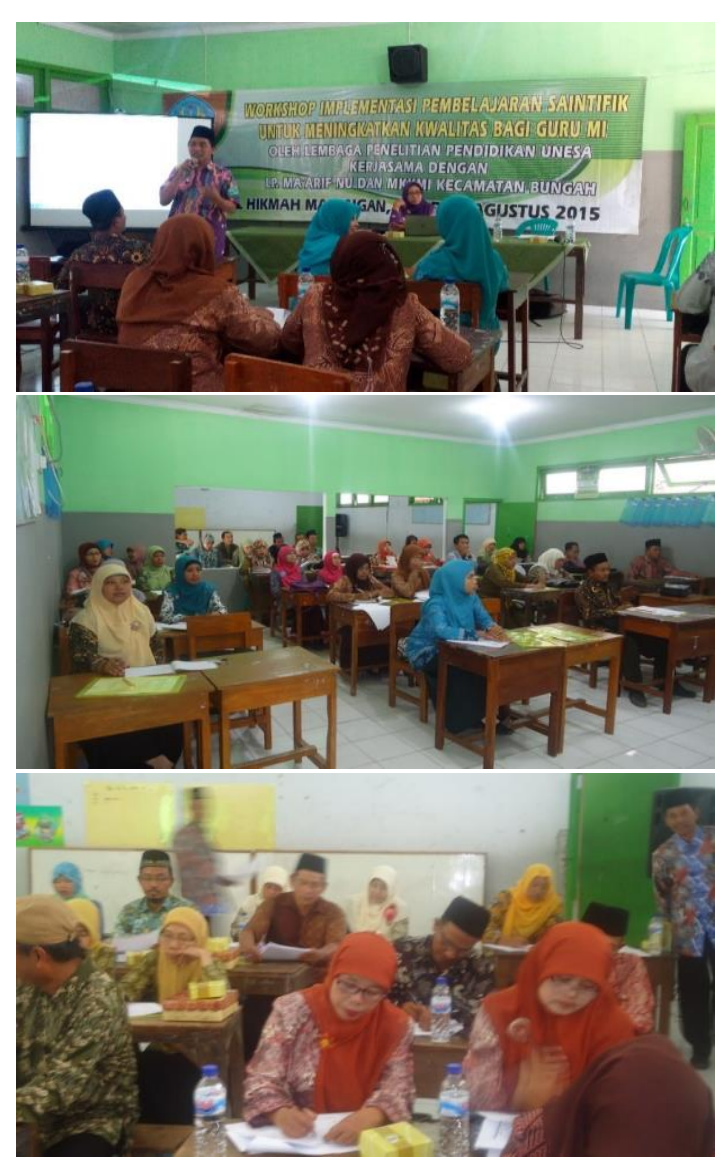

Gambar 1. Aktifitas peserta selama diskusi dan pengembangan perangkat pembelajaran di gedung $\mathrm{Ml} \mathrm{Al}$ Hikmah Bungah 
Kemampuan para guru dalam membuat perangkat pembelajaran saintifik disesuaikan dengan mata pelajaran yang diampu diketahui melalui hasil tugas membuat portofolio yang dilakukan oleh peserta. Penilaian hasil pengembangan perangkat terdiri dari perumusan tujuan pembelajaran, isi yang disajikan (kesesuain dengan pendekatan saintifik), waktu, bahasa, dan media. Hasil penilaian perangkat pembelajaran disajikan pada Tabel 2.

Tabel 2. Hasil Penilaian Perangkat Pembelajaran Peserta Pelatihan

\begin{tabular}{|c|c|c|c|c|c|c|c|c|c|}
\hline \multirow[t]{2}{*}{ No. } & \multirow[t]{2}{*}{ Kriteria Penilaian } & \multicolumn{7}{|c|}{ HASIL } & \multirow{2}{*}{$\begin{array}{l}\text { Rata- } \\
\text { rata }\end{array}$} \\
\hline & & Kel 1 & Kel 2 & Kel 3 & Kel 4 & Kel 5 & Kel 6 & Kel 7 & \\
\hline 1. & $\begin{array}{l}\text { Perumusan tujuan } \\
\text { pembelajaran, waktu, bahasa, } \\
\text { dan media }\end{array}$ & 5 & 5 & 5 & 4 & 4 & 5 & 5 & 4,7 \\
\hline 2. & $\begin{array}{l}\text { Isi yang disajikan (kesesuaian } \\
\text { dengan pendekatan saintifik) }\end{array}$ & 4 & 4 & 4 & 4 & 3 & 3 & 5 & 3,9 \\
\hline 3. & $\begin{array}{l}\text { Kesesuaian waktu yang } \\
\text { digunakan }\end{array}$ & 4 & 5 & 3 & 4 & 3 & 4 & 5 & 4 \\
\hline 4. & Bahasa yang digunakan & 4 & 4 & 4 & 4 & 4 & 3 & 5 & 4 \\
\hline & Media yang digunakan & 4 & 4 & 3 & 5 & 4 & 3 & 4 & 3,9 \\
\hline & al skor tiap Kelompok & 21 & 22 & 19 & 21 & 18 & 18 & 24 & \\
\hline $\mathrm{Ni}$ & & 84 & 88 & 76 & 84 & 72 & 72 & 96 & 81,7 \\
\hline
\end{tabular}

Sumber: data olahan peneliti

Berdasarkan Tabel 2 diketahui bahwa rata-rata kemampuan peserta dalam mengembangkan isi yang disajikan pada perangkat pembelajaran adalah mempunyai skor 3,9 (pada rentangan skor 1-5) namun secara keseluruhan peserta mampu memperoleh nilai 81,7 . Secara keseluruhan, peserta telah membuat portofolio yang sudah memenuhi kriteria yang telah ditentukan. Mereka telah dapat merencanakan pembelajaran saintifik dalam mata pelajaran yang mereka ampu kepada para siswa.

Penyusunan perangkat pembelajaran sudah mencakup mengamati, menanya, mengumpulkan informasi, mengolah informasi, dan mengkomunikasikan dan sesuai dengan pernyataan Kemendikbud (2013). Dalam pelaksanaan pengembangan perangkat masih perlu banyak feedback sehingga hasil perbaikannya lebih sempurna. Berdasarkan indikator pada Tabel 1 bahwa lebih dari $75 \%$ peserta telah mampu membuat perangkat pembelajaran dengan pendekatan saintifik. Dapat diketahui bahwa semua kelompok peserta mampu mengembangkan perangkat pembelajaran saintifik. Hal yang sama juga dilaporkan oleh Machin (2014) bahwa penerapan pendekatan saintifik berpengaruh positif terhadap hasil belajar kognitif, afektif dan psikomotorik serta telah mencapai ketuntasan klasikal yang ditetapkan.

Pendekatan saintifik dinilai berpengaruh lebih baik dari pada model pembelajaran langsung dalam meningkatkan hasil belajar biologi dan keterampilan proses sains peserta didik (Marjan et al. 2014). Penggunaan pendekatan saintifik untuk melatih guru IPA MI sangat sesuai untuk meningkatkan keterampilan mengembangkan RPP mereka. Penguasaan tahapan 5M diharapkan mampu meningkatkan kualitas pembelajaran IPA/sains di kelas.

Sains mengandung empat hal meliputi produk, proses, sikap dan teknologi, tidak hanya meliputi ranah kognitif saja (Rustaman dkk, 2003 ). Oleh karena itu, ketika pembelajaran sains berlangsung, siswa hendaknya mengalami keempat komponen tersebut, sehingga mereka dapat belajar aspek proses, sikap, dan teknologi agar siswa dapat benar-benar memahami sains secara utuh. Adapun tema science as inquiry pada dasarnya ialah metode ilmiah yang meliputi: 1) kemampuan menemukan masalah, 2) mencari alternatif pemecahan masalah, 3) membuat hipotesis, 4) merencanakan penelitian atau percobaan, 5) mengontrol variabel, 6) melakukan pengukuran, 7) mengorganisasi dan mernaknakan data, 8) membuat kesimpulan, serta 9) mengkomunikasikan hasil penelitian. Hal ini sesuai tuntutan kurikulum 2013 yakni pembelajaran melalui saintific approach, yaitu Mengamati, Menanya, Mengumpulkan informasi, Menalar dan Mengkomunikasikan (Kemendikbud, 2013). 
Semua komponen keterampilan proses dasar penting baik secara parsial maupun ketika terintegrasi secara bersama-sama. Keterampilan proses dasar merupakan fondasi bagi terbentuknya landasan berpikir logis. Oleh karena itu, sangat penting dimiliki dan dilatihkan bagi siswa sebelum melanjutkan ke keterampilan proses yang lebih rumit dan kompleks. Keterampilan proses sains dapat meletakkan dasar logika untuk meningkatkan kemampuan berpikir siswa bahkan pada siswa di kelas awal tingkat sekolah dasar. Di kelas awal, siswa lebih banyak menggunakan keterampilan proses sains yang mudah seperti pengamatan dan komunikasi, namun seiring perkembangannya mereka dapat menggunakan keterampilan proses sains yang kompleks seperti inferensi dan prediksi. Hasil penelitian Wijayanti (2014) bahwa autentic asessment berbasis proyek dengan pendekatan saintifik yang dikembangkan dapat meningkatkan keterampilan berpikir ilmiah dengan efektif. Setiap aspek keterampilan berpikir ilmiah mengalami peningkatan. Hal ini berarti pendekatan saintifik yang dilatihkan pada guru diyakini akan mampu meningkatkan keterampilan berpikir ilmiah dengan efektif pada siswa di kelas.

\section{Respon Peserta terhadap Pelaksanaan Pelatihan}

Indikator aspek ini adalah lebih dari 75\% peserta memberikan respons positif terhadap kegiatan pelatihan (Tabel 1). Hasil dari respon 65 orang guru (Tabel 3 ) yang mengisi angket tentang pelaksanaan kegiatan pelatihan implementasi pembelajaran saintifik dijabarkan melalui indikator fasilitator, materi, metode pelaksanaan, dan manfaat yang diperoleh peserta PKM. Berdasarkan indikator fasilitator PKM, 89\% responden menyatakan baik tentang penguasaan materi/kompetensi para fasilitator dalam menyampaikan materi pada kegiatan ini dan $86 \%$ menyatakan bahwa cara penyampaian materi oleh para fasilitator adalah baik.

Indikator kedua tentang materi PKM, 72\% responden menyatakan materi yang diberikan merupakan sesuatu yang baru sedangkan $28 \%$ responden lainnya menyatakan mereka sudah pernah mengetahui materi ini sebelumnya melalui sosialisasi atau pelatihan. Semua responden (100\%) menyatakan materi yang disampaikan dapat diterapkan dalam kegiatan pembelajaran. Indikator metode PKM yang digunakan dalam penyampaian materi sudah baik menurut 92\% responden. Alasan responden karena metode menarik dan mudah dipahami oleh peserta. Metode yang digunakan dalam pembuatan tugas portofolio menurut $78 \%$ responden menyatakan sudah baik sedangkan $22 \%$ responden menyatakan cukup. Peserta merasa waktunya masih perlu ditambah agar masing-masing peserta bisa mendapatkan waktu yang lebih banyak untuk diskusi.

Tabel 3. Hasil Tanggapan Peserta tentang Pelaksanaan Pelatihan

\begin{tabular}{|c|c|c|c|c|c|c|}
\hline \multirow[t]{2}{*}{ No. } & \multirow[t]{2}{*}{ Pernyataan } & \multicolumn{5}{|c|}{ Persentase (\%) } \\
\hline & & Ya & Tidak & Baik & Cukup & Kurang \\
\hline & $\begin{array}{l}\text { Penguasaan materi/kompetensi para } \\
\text { fasilitator dalam menyampaikan } \\
\text { materi }\end{array}$ & & & $89 \%$ & $11 \%$ & - \\
\hline 2. & $\begin{array}{l}\text { Cara penyampaian materi oleh para } \\
\text { fasilitator }\end{array}$ & & & $86 \%$ & $14 \%$ & - \\
\hline 3. & $\begin{array}{l}\text { Materi yang diberikan merupakan } \\
\text { sesuatu yang baru? }\end{array}$ & $72 \%$ & $28 \%$ & & & \\
\hline 4. & $\begin{array}{l}\text { Materi yang disampaikan dapat } \\
\text { diterapkan dalam kegiatan } \\
\text { pembelajaran }\end{array}$ & $100 \%$ & - & & & \\
\hline 5. & $\begin{array}{l}\text { Metode yang digunakan dalam } \\
\text { penyampaian materi }\end{array}$ & & & $92 \%$ & $8 \%$ & \\
\hline 6. & $\begin{array}{l}\text { Metode yang digunakan dalam } \\
\text { pembuatan portofolio }\end{array}$ & & & $78 \%$ & $22 \%$ & \\
\hline $\begin{array}{l}\text { - W } \\
\text { le } \\
\text { P }\end{array}$ & $\begin{array}{l}\text { ktunya masih perlu ditambah agar mas } \\
\text { h banyak untuk diskusi } \\
\text { lu dilakukan pelatihan pada materi yan }\end{array}$ & $\begin{array}{l}\text { an-sar } \\
\text {-masil } \\
\text { ain unt }\end{array}$ & eserta & 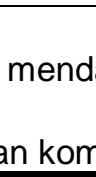 & 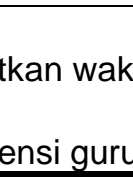 & lang \\
\hline
\end{tabular}


Kesan peserta selama mengikuti pelatihan adalah $100 \%$ peserta pelatihan merasa kegiatan pelatihan seperti ini memberikan manfaat untuk pengembangan kegiatan belajar-mengajar di kelas. Pembelajaran saintifik sangat berarti bagi siswa dan guru karena berdasarkan konsep ilmu sains yang harus dilalui oleh siswa selama prosesnya

Saran dari peserta untuk kegiatan selanjutnya antara lain waktu kegiatan di tambah, perlu dilakukan pelatihan yang semisal untuk meningkatkan kompetensi guru.

\section{SIMPULAN DAN SARAN}

Hasil kegiatan menunjukkan bahwa setelah mengikuti pelatihan, para peserta mampu mengembangkan RPP saintifik. Peserta memberikan tanggapan yang baik terhadap kegiatan pelatihan implementasi pembelajaran saintifik melalui pengembangan RPP mereka.

Saran untuk kegiatan selanjutnya perlu adanya tindak lanjut dari kegiatan pelatihan yang telah dilakukan dengan menambah alokasi waktu, materi pelatihan dan variasi metode yang diberikan.

\section{DAFTAR PUSTAKA}

Kemendikbud. 2013. Pengembangan Kurikulum 2013. Jakarta: Kementrian Pendidikan dan Kebudayaan.

Kemendikbud. 2013. Lampiran IV , Peraturan Menteri Pendidikan Dan Kebudayaan Republik Indonesia Nomor 81a
Tahun 2013, Tentang Implementasi Kurikulum Pedoman Umum Pembelajaran. Jakarta: Kementrian Pendidikan dan Kebudayaan.

Machin A. 2014. Implementasi Pendekatan Saintifik, Penanaman Karakter dan Konservasi pada Pembelajaran Materi Pertumbuhan. Jurnal Pendidikan IPA Indonesia Vol 3, No 1 (2014).

Marjan J, Arnyana IBP, Setiawan IGAN. 2014. Pengaruh Pembelajaran Pendekatan Saintifik terhadap Hasil Belajar Biologi dan Keterampilan Proses Sains Siswa MA Mu'allimat NW Pancor Selong Kabupaten Lombok Timur Nusa Tenggara Barat. Jurnal Program Pascasarjana Universitas Pendidikan Ganesha Vol. 4 No. 12014.

Media Pendidikan Indonesia. 2014. Pembelajaran Pendekatan Saintifik. http://www.medukasi.web.id/search/label/pengertian\% 20pembelajaran\%20saintifik diakses 20 Maret 2015.

Rustaman NY. dkk. 2003. Strategi Belajar Mengajar Biologi. Bandung: Jurusan Pendidikan Biologi FPMIPA UPI.

Wijayanti. 2014. Pengembangan Autentic Assesment Berbasis Proyek dengan Pendekatan Saintifik untuk Meningkatkan Keterampilan Berpikir IImiah Mahasiswa. Jurnal Pendidikan IPA Indonesia 3 (2) 2014: 102-108. 